\title{
EDITORIAL
}

\section{Utility of molecular epidemiology of tuberculosis}

\author{
D. van Soolingen
}

Just 10 yrs ago it was still generally accepted that bacteria of the Mycobacterium tuberculosis complex were so highly conserved, that phage typing, which could distinguish about 20 different phage types, was all one needed to study the epidemiology of tuberculosis [1-4]. From the late 1980s, repetitive deoxyribonucleic acid (DNA) sequences have been described, which are associated with different levels of genetic polymorphism [5-17]. In 1990, the highly similar insertion sequences IS986 and IS6110 were found in the genome of M. tuberculosis [10, 13, 14] and, when these elements were applied in restriction fragment length polymorphism (RFLP) typing, they provided an unprecedented degree of discrimination between $M$. tuberculosis complex isolates. When IS986-based RFLP typing was used in 1990 to confirm for the first time a suspected outbreak of tuberculosis in the Netherlands [8], interest in the molecular epidemiology of tuberculosis was awakened.

RFLP typing seemed ideal for studying small-scale transmission of $M$. tuberculosis, such as outbreaks in institutions, hospitals or among families [16, 18-22]. Within a remarkably short period of time the utility of fingerprinting for managing outbreaks was established. The RFLP typing technique was optimized and standardized to enable computer-assisted analysis of DNA fingerprints [23, 24]. This facilitated large-scale epidemiological studies. However, the utility and reliability of large-scale, or even routine, application of DNA fingerprinting in tuberculosis control is still debatable and hinges on whether clustering of DNA fingerprints among patients' isolates does truly reflect transmission of $M$. tuberculosis.

If clustering of cases on the basis of DNA fingerprinting does indeed reflect recent transmission, then the results from the population-based studies in San Francisco [25], New York [26], the Netherlands [27] and Denmark [28] would suggest that ongoing transmission contributes much more to the overall tuberculosis disease incidence in de-veloped countries than has been assumed previously. However, how do the results of these studies fit with other findings of the transmission of M. tuberculosis between different groups? Both Small et al. [25] (in San Francisco, USA) and van DeUTEKom et al. [29] (in Amsterdam, the Netherlands) found that only 5-10\% of the links indicated by DNA fingerprinting, were also found by conventional contact tracing. Furthermore, in the molecular epidemiological study in Bern, Switzerland, conducted by GENEwEIN et al. [30] cases in totally different social groups were in the same DNA fingerprint clusters.

Correspondence: D. van Soolingen, RIVM (LIS), Mycobacterial Dept, Postbus 1, 3720 BA Bilthoven, The Netherlands. Fax: 313027 44418.
To examine the utility of DNA fingerprinting in more detail, BRADEN et al. [31] chose another approach in the rural area of Arkansas, USA. In this study, extensive interviews with patients identified epidemiological connections for only 33 out of $78(42 \%)$ of the clustered patients. It is unclear whether the conclusions from this study can be generalized to other (e.g. urban) populations, as it was conducted in a rural area in which a large proportion of individuals were elderly.

In contrast, in the study of Burman et al. [32] (in Denver, USA) 40 of the 51 patients $(78 \%)$ with clustered isolates had definite or possible epidemiological links identified through contact tracing.

In the molecular epidemiological study in the metropolitan area of Zürich, Switzerland, presented by PFYFFer et al. [33] in this issue of the Journal, a very small percentage $(20 \%)$ of cases were clustered. This reflects that in an area where tuberculosis control is organized in a "Swiss way", it is possible to have very few cases clustered and that DNA fingerprinting is a sensitive tool for monitoring the performance of a tuberculosis control programme. However, even in this area, with a well-organized network for contact tracing, only a small proportion of the epidemiological relations indicated by DNA fingerprinting were confirmed by conventional contact tracing. In the Netherlands, isolates from all culture-positive cases have been DNA fingerprinted since 1993. DNA fingerprinting results, reported to the tuberculosis control services since 1995, are used in contact tracing and source case finding. The routine application of DNA fingerprinting in tuberculosis control in the Netherlands is currently being evaluated. As can be expected, some of the epidemiological connections indicated by DNA fingerprinting confirm those suspected in conventional contact tracing; these are usually the links which are easy to identify on the basis of sociodemogra-phic data. Other connections indicated by DNA fingerprinting results are less clear, or completely unexpected. For instance, there was recently a case of extra pulmonary tuberculosis in a 75 yr old woman, which was assumed to be attributable to the reactivation of a previous infection. She was socially isolated and did not leave her house during the manifestation of the disease. A home-visiting nurse, responsible for treating her tuberculous abscesses, became skin test positive and developed a pleural effusion, but otherwise no positive contacts were found. One year late, in the same village, pulmonary tuberculosis was diagno-sed in a $16 \mathrm{yr}$ old male. Contact tracing yielded no source case. To his best knowledge he had never contacted the female tuberculosis patient, as they were in completely different social groups and did not even know each other. It would have been impossible 
to link the two cases using conventional contact tracing. However, the DNA fingerprints of the isolates of these two patients were identical and had not yet been seen in the database of Dutch fingerprints.

Given that these fingerprints were observed in a very restricted geographical area, this finding cannot be attributed to any errors in the fingerprinting technique. This anecdote itself illustrates the fact that in the Netherlands clustered cases are frequently found in restricted geographic areas.

The strong negative correlation between age and clustering in population-based studies in the Netherlands and Cuba [27] (and Diaz et al., unpublished data) provides further evidence that clustering of DNA fingerprints does reflect recent transmission. In both studies, the percentage of cases clustered on the basis of DNA fingerprinting steadily decreased with age, reflecting that the proportion of disease attributable to endogenous reactivation increases with age.

In summary, the question arises as to whether we can assess the utility of DNA fingerprinting by comparing its findings with the results of conventional contact tracing, as this will only highlight the (lack of) correlation between the new and the classical approach. We may have to face the fact that transmission of $M$. tuberculosis occurs in ways that we have not previously imagined and that it cannot be predicted using sociodemographic data. Therefore, it is time to work from the opposite end of the spectrum and to use DNA fingerprinting results to start "open minded" investigations. All possible short, incidental contacts between clustered patients during a long-term period, which in current contact tracing policies would never be recorded, should be considered as possible routes of transmission. This may well change our ideas on the way a significant proportion of $M$. tuberculosis transmission occurs.

The utility of RFLP typing has been restricted by the need for large quantities of pure DNA; this is itself hampered by the slow growth rate of mycobacteria. RFLP typing results often only become available after the conventional contract tracing has been completed. Therefore, several polymerase chain reaction (PCR)-based methods have been developed recently [34-37], including one designated "spoligotyping", which simultaneously detects and types M. tuberculosis complex bacteria [34]. In theory, this method can be performed directly on clinical specimens (e.g. sputum), because it is based on the PCR. This circumvents a culture delay of 2-5 weeks. Unfortunately, the state of the art only allows a limited application of this technique, as this typing method is far less discriminatory than RFLP typing (DIAz et al., unpublished data).

Despite great advances in the development of molecular laboratory methodologies for the diagnosis of infectious diseases in recent years, the little genetic information that we do obtain comes only through laborious and demanding laboratory techniques. However, this situation will change shortly because of the developments in chip technology. It is already possible to generate approximately 20,000 oligonucleotide probes on a surface of $1 \mathrm{~cm}^{2}$ of high-density arrays with the aid of light-directed chemical synthesis [38]. The hybridization to the array can be read using epifluorescence confocal scanning. This means that, in principle, in one automated test the genetic information of an infectious agent with regard to evolutionary lineage at different levels, including strain-identification, resist- ance-related mutations, and possibly genetically defined virulence factors can be disclosed. This will certainly provide unprecedented knowledge to be used in our longstanding battle against tuberculosis and other infectious diseases.

\footnotetext{
Acknowledgement: The author would like to thank E. Vynnycky (London School of Hygiene and Tropical Medicine) for reading the manuscript and providing useful advice to improve it.
}

\section{References}

1. Crawford J, Bates JH. Phage typing of mycobacteria. In: Kubica GP, Wayne LG eds. The Mycobacteria: A Sourcebook. Part A. New York, Marcel Dekker, 1984; pp. 123132.

2. Gruft H, Johnson R, Claflin R, Loder A. Phage-typing and drug-resistance patterns as tools in mycobacterial epidemiology. Am Rev Respir Dis 1994; 130: 96-97.

3. Jones WD Jr. Geographic distribution of phage types among cultures of Mycobacterium tuberculosis from India and South Africa. Am Rev Respir Dis 1990; 142: 10001003.

4. Snider DE Jr, Jones WD, Good RG. The usefulness of phage typing Mycobacterium tuberculosis isolates. Am Rev Respir Dis 1984; 130: 1095-1099.

5. Collins DM, Stephens DM. Identification of insertion sequence. IS1081, in Mycobacterium bovis. FEMS Lett 1991; 83: 11-16.

6. Eisenach KD, Crawford JT, Bates JH. Repetitive DNA sequences as probes for Mycobacterium tuberculosis. $J$ Clin Microbiol 1988; 26: 2240-2245.

7. Hermans PWM, van Soolingen D, Bik EM, de Haas PEW, Dale JW, van Embden JDA. The insertion element IS987 from Mycobacterium bovis BCG is located in a hot spot integration region for insertion clements in Mycobacterium tuberculosis complex strains. Infect Immun 1991; 59: 2695-2705.

8. Hermans PWM, van Soolingen D, Dale JW, et al. Insertion element IS986 from Mycobacterium tuberculosis: a useful tool for diagnosis and epidemiology of tuberculosis. J Clin Microbiol 1990; 28: 2051-2058.

9. Hermans PWM, van Soolingen D, van Embden JDA. Characterization of a major polymorphic tandem repeat in Mycobacterium tuberculosis and its potential use in the epidemiology of Mycobacterium kansasii and Mycobacterium gordonae. J Bacteriol 1992; 174: 4157-4165.

10. McAdam RA, Hermans PWM, van Soolingen D, et al. Characterization of a Mycobacterium tuberculosis insertion sequence belonging to the IS3 family. Mol Microbiol 1990; 4: 1607-1613.

11. Reddi PP, Talwar GP, Khandekar PS. Repetitive DNA sequence of Mycobacterium tuberculosis: analysis of differential hybridization pattern with other mycobacteria. Int J Leprosy 1998; 56: 592-598.

12. Ross C, Raios K, Jackson K, Dwyer B. Molecular cloning of a highly repeated element from Mycobacterium tuberculosis and its use as an epidemiological tool. J Clin Microbiol 1992; 30: 942-946.

13. Thierry D, Brisson-Noël A, Vincent-Lévy-Frébault V, Nguyen S, Guesdon J, Gicquel JB. Characterization of a Mycobacterium tuberculosis insertion sequence, IS6110, and its application in diagnosis. J Clin Microbiol 1990; 28: 2668-2673. 
14. Thierry D, Cave MD, Eisenach KD, Crawford JT, Bates JH, Gicquel B, Guesdon JL. IS6110, an IS-like element of M. tuberculosis complex. Nucleic Acids Res 1990; 18: 188.

15. Van Soolingen D, de Haas PEW, Hermans PWM, Groenen $\mathrm{P}$, van Embden JDA. Comparison of various repetitive DNA elements as generic markers for strain differentiation and epidemiology of Mycobacterium tuberculosis. $J$ Clin Microbiol 1993; 31: 1987-1995.

16. Van Soolingen D, Hermans PWM, de Haas PEW, Soll DR, van Embden JDA. The occurrence and stability of insertion sequences in Mycobacterium tuberculosis complex strains: evaluation of IS-dependent DNA polymorphism as a tool in the epidemiology of tuberculosis. $J$ Clin Microbiol 1991; 29: 2578-2586.

17. Zainuddin ZF, Dale JW. Polymorphic repetitive DNA sequences in Mycobacterium tuberculosis detected with a gene probe from a Mycobacterium fortuitum plasmid. $J$ Gen Microbiol 1989; 135: 2347-2355.

18. Friedman CR, Stoeckle MY, Kreiswirth BN, et al. Transmission of multidrug-resistant tuberculosis in a large urban setting. Am J Respir Crit Care Med 1995; 152: 355359.

19. Otal I, Martin C, Vincent-Levy-Frebault V, Thierry D, Gicquel B. Restriction fragment length polymorphism using IS6110 as an epidemiological marker in tuberculosis. J Clin Microbiol 1991; 29: 1252-1254.

20. Beck-Sagué C, Dooley SW, Hutton MD, et al. Hospital outbreak of multidrug-resistant Mycobacterium tuberculosis infections. Factors of transmission to staff and HIVinfected patients. JAMA 1992; 268: 1280-1286.

21. Brian RE, Tokars JI, Grieco MH. An outbreak of multidrug-resistant tuberculosis among hospitalized patients with the acquired immunodeficiency syndrome. $N$ Engl $J$ Med 1992; 23: 1514-1521.

22. Griffith DE, Hardeman JL, Zhang Y, Wallace RJ, Mazurek GH. Tuberculosis outbreak among healthcare workers in a community hospital. Am J Respir Crit Care Med 1995; 152: 808-811.

23. Van Embden JDA, Cave MD, Crawford JT, et al. Strain identification of Mycobacterium tuberculosis by DNA fingerprinting: recommendations for a standardized methodology. J Clin Microbiol 1993; 31: 406-409.

24. Van Soolingen D, de Haas PEW, Hermans PWM, van Embden JDA. DNA fingerprinting of Mycobacterium tuberculosis. Meth Enzymol 1994; 235: 196-205.

25. Small PM, Hopewell PC, Singh SP, et al. The epidemiology of tuberculosis in San Francisco. N Engl J Med 1994; 330: 1703-1709.
26. Alland D, Kalkut GE, Moss AR, et al. Transmission of tuberculosis in New York City. N Engl J Med 1994; 330: 1710-1716.

27. Van Soolingen D. Use of DNA fingerprinting in the epidemiology of tuberculosis (dissertation). Utrecht, the Netherlands. University of Utrecht, 1996.

28. Yang ZH, de Haas PEW, Wachman CH, van Soolingen D, van Embden JDA, Anderson AB. Molecular epidemiology of tuberculosis in Denmark in 1992. J Clin Microbiol 1995; 33: 2077-2081.

29. Van Deutckom H, Gerritsen JJJ, van Soolingen D, van Ameijden EJC, van Embden JDA, Coutinho RA. A molecular epidemiological approach to studying the transmission of tuberculosis in Amsterdam. Clin Infect Dis 1997; 25: 1071-1077.

30. Genewein A, Telenti A, Bernasconi C, et al. Molecular approach to identifying route of transmission of tuberculosis in the community. Lancet 1993; 342: 841-844.

31. Braden CR, Templeton GL, Cave MD, et al. Interpretation of restriction fragment length polymorphism analysis of Mycobacterium tuberculosis isolates from a state with a large rural population. J Inf Dis 1997; 175: 1446-1452.

32. Burnan WJ, Reves RR, Hawkes AP, et al. DNA fingerprinting with two probes decreases clustering of $\mathrm{Myco}$ bacterium tuberculosis. Am J Respir Crit Care Med 1997; 155: 1140-1146.

33. Pfyffer GE, Strässle A, Rose N, Wirth R, Brändli O, Shang $\mathrm{H}$. Transmission of tuberculosis in the metropolitan area of Zurich: a 3 year survey based on DNA fingerprinting. Eur Respir J 1998; 11: 804-808.

34. Kamerbeek J, Schouls L, van Agterveld M, et al. Rapid detection and simultaneous strain differentiation of Mycobacterium tuberculosis for diagnosis and tuberculosis control. J Clin Microbiol 1997; 35: 907-914.

35. Friedman CR, Stoeckle MY, Johnson WD Jr, Riley LW. Double repetitive element PCR method for subtyping Mycobacterium tuberculosis clinical isolates. J Clin Microbiol 1995; 33: 1064-1069.

36. Haas WH, Butler WR, Woodley CL, Crawford JT. Mixedlinker polymerase chain reaction: a new method for rapid fingerprinting of isolates of the Mycobacterium tuberculosis complex. J Clin Microbiol 1993; 31: 1293-1298.

37. Plikaytis BB, Crawford JT, Woodley CL, et al. Rapid, amplification-based fingerprinting of Mycobacterium tuberculosis. J Gen Microbiol 1993; 139: 1537-1542.

38. Lipshutz RJ, Morris D, Chee M, et al. Using oligonucleotide probe arrays to access genetics diversity. BioFeature 1995; 19: 442-446. 